\title{
Tanggung Jawab Notaris atas Pemalsuan yang Dilakukan oleh Klien dalam Proses Pembuatan Akta
}

\section{Notary Responsibilities for The Making of Clients Containing False Elements in The Process of Making The Deed}

\author{
Ayu Rizkie*, Muhammad Arifin \& Ramlan \\ Program Studi Magister Kenotariatan, Fakultas Hukum, \\ Universitas Muhammadiyah Sumatera Utara, Indonesia
}

Diterima: 01 Maret 2020; Disetujui: 13 Maret 2020; Dipublish: 23 Maret 2020

*Coresponding Email: avu.rizkie22@mail.com

\section{Abstrak}

Penulisan ini bertujuan untuk mengkaji dan menganalisis akibat hukum terhadap akta yang mana dalam proses pembuatannya mengandung unsur pemalsuan. Masalah yang dibahas dalam tulisan ini berfokus pada analisis pertanggungjawaban pidana terhadap notaris pada putusan Pengadilan Negeri Padang Nomor 535/Pid.B/2013/PN.Pdg dan akibat hukumnya yang dalam proses pembuatannya mengandung unsur penipuan. Metode penelitian tulisan ini menggunakan metode penelitian yuridis normatif, dengan pendekatan yuridis empiris yang akan mengkaji dan menganalisis putusan yang berkaitan dengantanggungjawab notaris. Hasil dari pada penulisan ini menunjukkan bahwa akibat hukum terhadap akta yang mana dalam proses pembuatannya mengandung unsur pemalsuan tersebut dapat dibatalkan, pembatalan suatu akta merupakan sanksi terhadap perbuatan hukum yang mengandung unsur cacat yuridis (penyebab kebatalan) dan tidak pula memiliki akibat hukum sejak terjadi pembatalan terhadap pihak-pihak yang disebut dalam akta. Pertanggung jawaban pidana terhadap notaris dalam putusan Pengadilan Negeri Padang Nomor 535/Pid.B/2013/PN.Pdg, pada dasarnya telah memenuhi unsur baik dari segi kemampuan untuk bertanggung jawab dan adanya kesalahan, dan tidak adanya alasan pemaaf, ketiga unsur tersebut telah terpenuhi sehingga secara hukum notaris selaku terdakwa dapat dimintakan pertanggungjawaban pidana terhadapnya.

Kata Kunci: Tanggung Jawab Notaris, Akta, Pidana, Pemalsuan.

\begin{abstract}
This writing aims to review and analyze the legal consequences of the deed which in the process of making it contain elements of forgery, the issues discussed in this paper focus on analyzing criminal liability against the notary public in the decision of the Padang District Court Number 535 / Pid.B / 2013 / PN.Pdg and legal consequences to those in the manufacturing process which contain an element of fraud. The research method of this paper is a normative juridical research method, with an empirical juridical approach that will review and analyze decisions relating to notary responsibilities. The results of this paper show that the legal consequences of the deed which in the process of making it contain elements of forgery can be canceled, the cancellation of a deed is a sanction against legal actions that contain elements of juridical defects (causes of cancellation) and also has no legal consequences since the cancellation of parties referred to in the deed. The criminal liability against the notary public in the decision of the Padang District Court Number 535 / Pid.B / 2013 / PN.Pdg, has fulfilled both elements in terms of the ability to be responsible and errors, and the absence of forgiving reasons, all three elements have been fulfilled so that the legal notary as the defendant can be held liable for criminal action against him.
\end{abstract}

Keywords: Responsibility of Notary, Deed, Criminal, Counterfeiting.

How to Cite: Rizkie, A., Arifin, M. \& Ramlan. (2020). Tanggung Jawab Notaris Atas Perbuatan Klien yang Mengandung Unsur Pemalsuan dalam Proses Pembuatan Akta. Journal of Education, Humaniora and Social Sciences (JEHSS). 2(3): 583 - 596 


\section{PENDAHULUAN}

Indonesia merupakan negara hukum (rechtstaat) di mana prinsip negara hukum adalah menjamin kepastian, ketertiban dan perlindungan hukum yang berintikan kebenaran dan keadilan (Puri, 2011). Keberadaan notaris di Indonesia tetap diakui berdasarkan ketentuan Pasal 2 Aturan Peralihan Undang-Undang Dasar 1945, yaitu segala peraturan perundang-undangan yang ada masih tetap berlaku selama belum diadakan yang baru menurut Undang-Undang Dasar ini, dengan demikian peraturan tentang notaris pada zaman penjajahan Belanda yaitu Reglement op Het Notaris Ambt in Nederlads Indie (Stbl, 1860) tetap berlaku di Indonesia.

Berlakunya Undang-Undang Nomor 30 Tahun 2004 Tentang Jabatan Notaris telah melahirkan perkembangan hukum dalam dunia kenotariatan pada saat ini, di mana adanya perluasan kewenangan Notaris, sebagaimana yang dimaksud dalam Pasal 1 Ayat (1) Undang-Undang Nomor 30 Tahun 2004 Tentang Jabatan Notaris, yang menyatakan bahwa notaris adalah pejabat umum yang berwenang untuk membuat akta autentik dan kewenangan lainnya. Keberadaan notaris terdapat dalam Kitab Undang-Undang Hukum Perdata, terutama dalam Buku Keempat tentang Pembuktian dan Kedaluwarsa, kemudian mengenai alat bukti yang utama dalam hukum perdata adalah bukti tertulis, sedangkan alat bukti tertulis yang paling kuat adalah berbentuk akta autentik. (Santoso, 2012)

Notaris adalah pejabat umum yang diangkat oleh pemerintah untuk membantu masyarakat umum dalam hal membuat perjanjian-perjanjian yang ada atau timbul dalam masyarakat. Perlunya perjanjian-perjanjian tertulis ini dibuat dihadapan seorang notaris adalah untuk menjamin kepastian hukum serta untuk memenuhi hukum pembuktian yang kuat bagi para pihak yang melakukan perjanjian, kebutuhan akan pembuktian tertulislah yang mengkehendaki sangat pentingnya lembaga kenotariatan ini. Notaris sebagai pejabat umum yang membuat akta autentik, wajib secara mandiri dan tidak berpihak melindungi kepentingan anggota masyarakat yang meminta jasanya, merahasiakan isi akta yang dibuat dihadapannya dan tidak sembarangan memberitahukan atau membocorkan isi akta dan keterangan lain yang berkaitan dengan akta, yang diberitahukan oleh yang berkepentingan kepadanya, agar tidak diketahui oleh umum atau pihak lain yang tidak ada kaitannya (Oloan, 2016). 
Pada proses pembuatan akta tidak jarang klien melakukan pemalsuan surat baik yang diketahui oleh notaris ataupun tidak diketahui oleh notaris dengan maksud untuk mempercepat administrasi serta pengurusan suatu akta. Klien melakukan cara-cara yang melanggar hukum, seperti pemalsuan surat atau dokumen, baik segi isi maupun lainnya seperti pemalsuan tanda tangan, dan lain sebagainya, hal inilah yang tidak menutup kemungkinan dapat menyeret notaris sebagai pembuat akta autentik ke dalam suatu permasalahan hukum.

Terlibatnya notaris dalam tindak pidana pemalsuan pada proses pembuatan akta masih sering terjadi, hal itu terlihat dengan adanya Putusan Pengadilan Negeri Padang Nomor 535/Pid.B/2013/PN. Pdg, di mana dalam putusan ini pemalsuan yang dilakukan oleh notaris dalam bentuk pemalsuan surat kuasa. Pemalsuan surat dapat terjadi dalam hal membuat dan meniru tanda tangan seseorang yang tidak ada orangnya terlihat untuk menandatangani langsung surat tersebut (Lubis, 1994). Tujuan penelitian ini adalah untuk mengetahui akibat hukum terhadap akta yang dalam proses pembuatannya mengandung unsur penipuan, dan menganalisis pertanggungjawaban pidana terhadap notaris yang terlibat dalam pembuatan akta yang mengandung unsur penipuan pada putusan Pengadilan Negeri Padang Nomor 535/Pid.B/2013/PN.Pdg.

\section{METODE PENELITIAN}

Metode penelitian yang penulis gunakan dalam penelitian ini adalah penelitian kualitatif yang mengacu pada jenis penelitian yuridis normatif, dimana menurut Sunggono metode penelitian ini dapat digunakan untuk menarik asaa-asas hukum dalam menafsirkan peraturan perundang-undangan, selain itu penelitian ini juga dapat digunakan untuk mencari asas hukum yang dirumuskan baik secara tersirat maupun tersurat. (Sunggono, 2003)

Dengan jenis pendekatan yuridis normatif inilah yang akan digunakan untuk mengkaji dan menganalisis putusan yang berkaitan dengan tanggung jawab notaris atas perbuatan klien yang mengandung unsur pemalsuan dalam proses pembuatan akta dengan menggunakan sumber data dari bahan hukum primerdan sekunder yakni, Undang-Undang Nomor 2 Tahun 2014 Tentang Jabatan Notaris dan peraturan serta peraturan perundang-undangan lainnya yang relevan dengan penelitian ini dan Putusan 
Ayu Rizkie, Muhammad Arifin \& Ramlan. Tanggung Jawab Notaris Atas Perbuatan Klien yang

Pengadilan Negeri Padang Nomor 535/Pid.B/2013/PN. Pdg, kemudian dokumen lainnya yang berkaitan dengan penelian ini seperti buku-buku, jurnal hukum, dan lain-lainnya.

\section{HASIL DAN PEMBAHASAN}

Akibat Hukum Terhadap Akta Yang Dalam Proses Pembuatannya Mengandung Unsur Pemalsuan

\section{Ketentuan Hukum Pidana Pemalsuan dalam Pembuatan Akta Autentik}

Tindak pidana adalah kelakuan (handeling) yang diancam dengan pidana, yang bersifat melawan hukum, yang berhubungan dengan kesalahan dan dilakukan oleh orang yang mampu bertanggung jawab (cakap hukum), dirumuskan dalam ketentuan undangundang, melawan hukum, yang patut dipidana dan dilakukan dengan adanya kesalahan. (Andrisman, 2007)

Pengaturan mengenai tindak pidana pemalsuan dalam pembuatan akta autentik diatur dalam ketentuan Pasal 263 dan Pasal 266 KUHP yang menyebutkan Barang siapa membuat secata tidak benar atau memalsukan surat yang dapat menimbulkan hak, perikatan atau pembebasan hutang, atau diperuntukkan sebagai bukti dari suatu hal, dengan maksud untuk memakai atau menyuruh orang lain memakai surat tersebut seolah-olah isinya benar dan tidak dipalsukan, diancam, jika pemakaian tersebut dapat menimbulkan kerugian, karena pemalsuan surat dengan pidana penjara paling lama enam tahun (Pasal 263 ayat 1), Selanjutnya pada ayat (2) Dengan hukuman serupa itu juga dihukum barang siapa dengan sengaja menggunakan surat palsu atau yang dipalsukan itu seolah-olah surat itu asli dan tidak dipalsukan kalau hal mempergunakan dapat mendatangkan suatu kerugian.

Unsur-unsur yang dapat diuraikan dari Pasal 263 ini berdasarkan teori hukum pidana maka dapat dilihat dua unsur besarnya yaitu objektif dan unsur subjektif dimana unsur objektif meliputi perbuatan: membuat surat palsu, memalsukan objek surat yang dapat menimbulkan hak, menimbulkan suatu perikatan, pembebasan hutang, dapat diperuntukkan untuk pembuktian suatu hal, dapat menimbulakan akibat kerugian dari pemakaian surat tersebut. Sedangkan unsur subjektif dalam pasal ini yaitu dengan maksud dan tujuan untuk menggunakannya sebagai surat asli dan tidak dipalsukan atau untuk membuat orang lain menggunakan surat tersebut. 
Pasal 266 KUHP menyatakan Barang siapa menyuruh memasukkan keterangan palsu dalam suatu akta autentik mengenai hal yang kebenarannya harus dinyatakan oleh akta itu, dengan maksud untuk memakai atau menyuruh orang lain memakai akta itu seolah-olah keterangannya sesuai dengan kebenaran, diancam, jika pemakaian itu dapat menimbulkan kerugian dengan piadana penjara paling lama tujuh tahun (ayat 1), pada ayat (2) diterangkan diancam dengan pidana yang sama barang siapa dengan sengaja memakai akta tersebut seolah-olah isinya sesuai dengan kebenaran, jika karena pemakaian tersebut dapat menimbulkan kerugian.

Berdasarkan hal tersebut di atas menunjukkan bahwa delik pemalsuan memiliki beberapa unsur di mana unsur yang hingga sekarang masih belum jelas adalah soal akibat yang ditimbulkannya, apakah mutlak ada atau tidak. Pasal 263 KUHP misalnya, akibat yang ditimbulkan dari perbuatan pemalsuaan adalah timbulnya sesuatu hak, perikatan atau pembebasan hutang, atau yang diperuntukkan sebagai bukti, dalam konteks ini salah satu dari empat akibat yang dilarang ini harus muncul, jika salah satu tidak timbul, maka tidak dapat digolongkan sebagai delik, demikian juga dengan Pasal 266 KUHP, akibat yang dilarang adalah timbulnya kerugian, jika kerugian tidak timbul, maka dapa ditafsirkan delik ini tidak sempurna. Bagi pelanggaran materil profesi notaris, pasal pidana yang dapat dikenakan adalah dengan tuduhan tindak pidana pemalsuan surat, di mana tindak pidana ini dapat dikenakan kepada notaris dengan 20 ancaman maksimal 6 (enam) sampai 7 (tujuh) tahun penjara.

Pemalsuan terhadap isi surat yang sering terjadi dilakukan oleh pekerja notaris misalnya dalam hal penandatanganan terhadap surat-surat yang seharusnya di tandatangani oleh yang lebih berwenang, selain itu juga dimungkinkan pekerja notaris membuat surat palsu terhadap surat yang seharusnya di buat oleh instansi lain yang berwenang untuk itu, di mana surat tersebut adalah sebagai syarat pelengkap dalam pembuatan akta autentik. Berdasarkan Putusan Pengadilan Negeri Padang Nomor 535/Pid.B/2013/PN. Pdg, pemalsuan surat yang dilakukan oleh notaris dan pekerja notaris adalah pemalsuan surat kuasa, di mana dalam surat kuasa yang dibuat oleh terdakwa ada pemalsuan tanda tangan.

Membuat surat palsu dapat terjadi pula apabila ada tanda tangannya yang tidak benar, hal ini dapat terjadi dalam hal misalnya membuat dengan meniru tanda tangan seseorang yang tidak ada orangnya, seperti orang yang telah meninggal dunia. Notaris 
dan pekerja notaris juga dimungkinkan membuat surat palsu terhadap surat yang seharusnya di buat oleh instansi lain yang berwenang untuk itu, di mana surat tersebut adalah sebagai syarat pelengkap dalam pembuatan akta autentik, dan dalam hal pekerja notaris melakukan tindak pidana pemalsuan surat terhadap akta yang akan di buat oleh notaris, notaris harus hati-hati dan memperhatikan betul atas semua surat yang dijadikan sebagai bahan dalam pembuatan akta autentik, karena apabila lalai dan terbukti adanya tindak pidana pemalsuan oleh pekerja notaris, tidak menutup kemungkinan notaris bertanggung jawab atas apa yang dilakukan oleh pekerjanya.

\section{Akibat Hukum Terhadap Akta yang dalam Proses Pembuatannya Mengandung Unsur Pemalsuan}

Akta Notaris pada hakekatnya memuat keterangan bahwa para pihak benar berkata kepada notaris. Dengan kata lain notaris mempunyai kewajiban untuk memasukkan dalam akta tentang apa yang sungguh-sungguh telah dimengerti oleh para pihak dan membacakannya sehingga menjadi jelas isi akta tersebut. Dalam pembuatan akta notaris memamang bukan tugas notaris untuk menyelidiki kebenaran tentang apa yang diberitahukan oleh para pihak kepada notaris namun hal tersebut harus didukung oleh bukti-bukti pendukung (Din, 2019).

Alasan secara yuridis secara umum diluar dari aturan undang-undang yang mengakibatkan kebatalan dan pembatalan akta notaris yang pada umumnya sama dengan alasan-alasan yuridis batalnya perjanjian. Cacatnya akta notaris dapat menimbulkan kebatalan bagi suatu akta notaris dan mengakibatkan perbuatan hukum tersebut menjadi tidak berlaku atau tidak mempunyai akibat hukumnya, dan adapun sebab-sebab tersebut yaitu: tidak memenuhi syarat objektif suatu perjanjian, ketidakcakapan absolut, ketidakwenangan bertindak, bertentangan dengan undangundang, ketertiban umum atau kesusilaan, kerpenuhinya peristiwa hukum dalam perjanjian dengan syarat batal, ketidakcakapan relatif, cacat kehendak, penyalahgunaan keadaan (misbruik van omstandigheiden), wanprestasi sebagai syarat batal, tidak terpenuhinya bentuk perjanjian formil.

Implikasi hukum mengenai kebatalan dan pembatalan akta notaris berdasarkan Undang-Undang Nomor 2 Tahun 2014 Tentang Perubahan Atas Undang-Undang Nomor 30 Tahun 2004 tentang Jabatan Notaris yaitu sebagai berikut: Akta notaris dapat 
dibatalkan berdasarkan ketentuan Undang-Undang Jabatan Notaris, pada Pasal 15 telah diatur mengenai kewenangan Notaris sebagaimana dinyatakan bahwa notaris berwenang membuat akta autentik mengenai semua perbuatan, perjanjian, dan penetapan yang diharuskan oleh peraturan perundangundangan dan/atau yang dikehendaki oleh yang berkepentingan untuk dinyatakan dalam akta autentik, menjamin kepastian tanggal pembuatan akta, menyimpan akta, memberikan grosse, salinan dan kutipan akta, semuanya itu sepanjang pembuatan aktaitu tidak juga ditugaskan atau dikecualikan kepada pejabat lain atau orang lain yang ditetapkan oleh undang-undang. (Adjie, 2008)

Selain kewenangan sebagaimana yang dimaksud pada ayat (1), Notaris berwenang pula mengesahkan tanda tangan dan menetapkan kepastian tanggal surat di bawah tangan dengan mendaftarkan dalam buku khusus, membukukan surat-surat di bawah tangan dengan mendaftar dalam buku khusus, membuat fotokopi dari asli surat di bawah tangan berupa salinan yang memuat uraian sebagaimana ditulis dan digambarkan dalam surat yang bersangkutan, melakukan pengesahan kecocokan fotokopi dengan surat aslinya, memberikan penyuluhan hukum sehubungan dengan pembuatan akta, membuat akta yang berkaitan dengan pertanahan atau membuat akta risalah lelang (Santono, 2012). Selain kewenangan sebagaimana dimaksud pada ayat (1) dan (2), Notaris mempunyai kewenangan lain yang diatur dalam perundangundangan. Akta notaris dapat dibatalkan adalah sanksi terhadap suatu perbuatan hukum yang mengandung cacat yuridis (penyebab kebatalan) berupa pembatalan perbuatan hukum atas keinginan pihak tertentu dan akibat hukum dari pembatalan itu yaitu perbuatan hukum tersebut tidak mempunyai akibat hukum sejak terjadinya pembatalan, dan pembatalan atau pengesahan perbuatan hukum tersebut tergantung pada pihak tertentu, yang menyebabkan perbuatan hukum tersebut dapat dibatalkan atau disahkan.

Pembuatan akta, terutama syaratsyarat para pihak yang menghadap notaris tidak memenuhi syarat subjektif, maka atas permintaan orang tertentu akta tersebut dapat dibatalkan. Akta yang dapat dibatalkan dapat disebabkan karena tidak terpenuhinya unsur subjektif dalam perjanjian. Unsur subjektif dalam perjanjian ini meliputi kecakapan dan kesepakatan, di mana kesepakatan antara para pihak, yaitu persesuaian pernyataan kehendak antara kedua belah pihak, tidak ada paksaan dan lainnya. Mulai berlakunya pembatalan di dalam akta notaris yang dapat dibatalkan adalah akta notaris 
Ayu Rizkie, Muhammad Arifin \& Ramlan. Tanggung Jawab Notaris Atas Perbuatan Klien yang

akan tetap mengikat para pihak yang bersangkutan selama belum ada putusan pengadilan yang memiliki kekuatan hukum tetap, tetapi akta notaris menjadi tidak mengikat sejak ada putusan pengadilan yang memiliki kekuatan hukum tetap yang menyatakan akta notaris tersebut menjadi tidak sah dan tidak mengikat. Akta notaris batal demi hukum apabila suatu akta notaris tidak memenuhi unsur-unsur obyektif dalam perjanjian maka akta notaris tersebut dapat menjadi batal demi hukum.

Batal demi hukum adalah sanksi perdata terhadap suatu perbuatan hukum yang penyebab kebatalan mengandung cacat yuridis (penyebab kebatalan), berupa perbuatan hukum yang dilakukan tidak mempunyai akibat hukum sejak terjadinya perbuatan hukum tersebut atau perbuatan hukum tersebut menjadi tidak berlaku sejak akta ditandatangani dan tindakan hukum yang disebut dalam akta dianggap tidak pernah terjadi. Menyebabkan akta notaris menjadi batal demi hukum yaitu apabila melanggar ketentuan dalam undang-undang yaitu: Pelanggaran Pasal 16 ayat (1) huruf I UU 2/2014 Tentang Jabatan Notaris berupa tidak membuat daftar wasiat dan tidak mengirimkan laporan dalam jangka waktu yang telah ditentukan. Pasal 16 ayat (1) huruf K, tentang cap/stempel notaris, Pasal 44 tentang penandatangan akta notaris dan kewajiban notaris untuk menjelaskan kepada penghadap. Pasal 48 tentang notaris yang mengatur larangan perubahan isi akta. Pasal 50 mengatur pencoretan kata, huruf dan angka, Pasal 51 yang mengatur kewenangan notaris untuk membetulkan kesalahan tulis.

Akta notaris yang mempunyai kekuatan pembuktian sebagai akta di bawah tangan Pasal 1869 Kitab Undang-Undang Hukum Perdata menentukan batasan akta notaris yang mempunyai kekuatan pembuktian sebagai akta di bawah tangan dapat terjadi jika tidak memenuhi ketentuan karena: tidak berwenangnya pejabat umum yang bersangkutan, cacat dalam bentuknya meskipun demikian akta seperti itu tetap mempunyai kekuatan pembuktian sebagai akta di bawah tangan jika akta tersebut ditandatangani oleh para pihak. Ketentuan-ketentuan tersebut di bawah ini dicantumkan secara tegas dalam pasal-pasal tertentu yang menyebutkan jika dilanggar oleh notaris, sehingga akta notaris mempunyai kekuatan pembuktian sebagai akta di bawah tangan yaitu: melanggar Pasal 16 ayat (7) dan (8), Pasal 41, 52.

Pelanggaran terhadap ketentuan tersebut mengakibatkan akta notaris mempunyai kekuatan pembuktian sebagai akta di bawah tangan, dan dengan demikian dapat disimpulkan bahwa akta notaris yang mempunyai kekuatan pembuktian sebagai akta di 
bawah tangan, jika disebutkan dengan tegas dalam pasal yang bersangkutan, dan yang tidak disebutkan dengan tegas dalam pasal yang bersangkutan mulai berlaku sebagai akta di bawah tangan selama belum ada putusan hakim yang memiliki kekuatan hukum tetap akta tersebut tetap sah dan mengikat, dan akta notaris tersebut menjadi tidak mengikat setelah ada putusan hakim yang mempunyai kekuatan hukum tetap yang menyatakan akta tersebut mempunyai kekuatan pembuktian sebagai akta di bawah tangan. (Ningsi \& Faisal, 2019) Berdasarkan hal tersebut di atas maka akibat hukum terhadap akta yang dalam proses pembuatannya mengandung unsur pemalsuan adalah terhadap akta notaris tersebut dapat dibatalkan sebab tidak adanya kesepakatan dalam pembuatan akta tersebut. Akta notaris harus memuat adanya kesepakatan para pihak yang akan membuat perjanjian di dalam akta notaris tersebut. Kebebasan bersepakat tersebut dapat terjadi secara tegas (mengucapkan kata maupun tertulis) atau secara diam (dengan suatu sikap atau isyarat) dengan tanpa adanya unsur paksaan, kekeliruan dan unsur penipuan antara para pihak.

\section{Pertanggungjawaban Pidana Notaris Pada Putusan Pengadilan Negeri Padang Nomor 535/Pid.B/2013/Pn. Pdg Dalam Hal Akta Yang Dibuat Notaris Mengandung Unsur Pemalsuan}

\section{Konsep Pertanggungjawaban Pidana dalam Konteks Hukum Positif Indonesia}

Pertanggungjawaban pidana sudah muncul sejak zaman revolusi, pada masa itu tidak saja manusia yang dapat dikenakan pertanggungjawaban tindak pidana bahkan hewan atau benda mati lainya pun dapat dikenakan pertanggungjwabkan tindak pidana. Seseorang tidak saja mempertanggungjawabkan tindak pidana yang dilakukannya, akan tetapi perbuatan orang lain juga dapat dipertanggungjawabkan karena pada masa itu hukuman tidak hanya terbatas pada pelaku sendiri tetapi juga dijatuhkan pula pada keluarga atau teman-teman pelaku meskipun mereka tidak melakukan tindak pidana. Pertanggungjawaban pidana dapat diartikan diteruskannya celaan objektif yang ada pada perbuatan pidana dan secara subjektif yang memenuhi syarat untuk dapat dipidana karena perbuatannya itu. (Ali, 2015)

Pertanggungjawaban pidana adalah tanggung jawab seseorang secara pidana atas perbuatan yang melawan atau melanggar hukum, di mana dalam ketentuan hukum tersebut memuat sanksi pidana. Pemberian hukuman sangat erat kaitanya dengan 
Ayu Rizkie, Muhammad Arifin \& Ramlan. Tanggung Jawab Notaris Atas Perbuatan Klien yang

pertanggungjawaban pidana di mana orang yang dihukum harus mampu mempertanggungjawabkan perbuatannya. Pertanggungjawaban pidana harus sesuai dengan asas hukum pidana tentang pertanggungjawaban pidana yang berbunyi tidak dipidana jika tidak ada kesalahan (geen straf zonder schuld actus non facit reum nisi mens sist rea) (Moeljatno: 1993). Secara teori ada tiga kosep pertanggungjawaban pidana agar seseorang bisa mempertanggungjawabkan tindak pidana yang dilakukannya, di mana ketiga konsep itu adalah, Kemampuan bertanggung jawab merupakan unsur atau (elemen) kesalahan, oleh karena itu untuk membuktikan adanya kesalahan, unsur tadi harus dibuktikan pula.

Pada umumnya setiap orang adalah normal batinnya, dan mampu bertanggung jawab, maka unsur ini dianggap diam dan selalu ada, kecuali kalau ada tanda-tanda yang menunjukkan bahwa terdakwa mungkin jiwanya tidak normal, dan dalam hal ini hakim harus memerintahkan pemeriksaan yang khusus terhadap keadaan jiwa terdakwa tersebut sekalipun tidak diminta oleh pihak terdakwa dan jika hasilnya memang jiwanya tidak normal, maka pidana tidak dapat dijatuhkan atau jika hasil pemeriksaan masih meragukan bagi hakim, itu berarti bahwa adanya kemampuan bertanggung jawab tidak terbukti, sehingga kesalahan tidak ada, dan pidana tidak dapat dijatuhkan, berdasar atas asas tidak dipidana jika tidak ada kesalahan.

\section{Adanya Kesalahan dan Kealpaan}

Sesorang dapat dikatakan mempunyai kesalahan, jika dia pada waktu melakukan perbuatan pidana, dilihat dari segi masyarakat dapat dicela karenanya yaitu mengapa melakukan perbuatan yang merugikan masyarakat, padahal mampu untuk mengetahui makna (jelek) perbuatan tersebut, dan karenanya dapat atau bahkan harus menghindari untuk berbuat demikian, tentunya perbuatan tersebut memang sengaja dilakukan, dan celaannya berupa mengapa melakukan perbuatan, sedangkan dia mengerti bahwa perbuatan itu merugikan masyarakat. Pemidanaan masih memerlukan adanya syarat, yaitu bahwa orang yang melakukan perbuatan itu mempunyai kesalahan atau bersalah (subjective guilt) berdasarkan asas tiada pidana tanpa kesalahan (geen straf zonder schuld) atau (nulla poena sine culpa) di mana culpa di sini dalam arti luas meliputi kesengajaan (Moeljatno, 1993). Kitab hukum pidana tidak menyebutkan secara eksplisit mengenai sistem pertanggungjawaban pidana yang dianut. 


\section{Alasan penghapus pidana}

Alasan penghapus pidana adalah peraturan yang terutama ditujukan kepada hakim, di mana peraturan ini menetapkan berbagai keadaan pelaku, yang telah memenuhi perumusan delik sebagaimana yang telah diatur dalam undang-undang yang seharusnya dipidana, akan tetapi tidak dipidana. Hakim dalam hal ini menempatkan wewenang di dalam dirinya (dalam mengadili perkara yang konkret) sebagai penentu apakah telah terdapat keadaan khusus dalam diri pelaku, seperti dirumuskan dalam alasan penghapus pidana (Hamdan, 2008).

Alasan penghapus pidana dapat dibagi menjadi dua, yaitu alasan penghapus pidana yang merupakan alasan pemaaf dan yang kedua alasan penghapus pidana yang merupakan alasan pembenar. Alasan penghapus pidana yang merupakan alasan pemaaf adalah alasan-alasan yang menghapuskan kesalahan yang dilakukan oleh pelaku atau terdakwa, oleh karena alasan ini menyangkut tentang kesalahan pelaku, maka alasan penghapus pidana ini hanya berlaku untuk diri pribadi sipelaku atau terdakwa. Alasan pembenar adalah alasan-alasan yang menghapuskan sifat melawan hukum perbuatannya, oleh karena alasan penghapus pidana ini menyangkut tentang perbuatan, maka alasan ini berlaku untuk semua orang yang melakukan perbuatan tersebut.

\section{Subjek Pertanggungjawaban Pidana pada Tindak Pidana Pemalsuan dalam Pembuatan Akta Autentik}

Subjek pertanggungjawaban pidana merupakan subjek tindak pidana, karena berdasarkan uraian-uraian $\mathrm{di}$ atas telah dibahas bahwa yang akan mempertanggungjawab akan suatu tindak pidana adalah pelaku tindak pidana itu sendiri sehingga sudah barang tentu subjeknya haruslah sama antara pelaku tindak pidana dan yang akan mempertanggungjawabkan perbuatan pidananya. Subjek tindak pidana adalah manusia (natuurlijke persoonen), sedangkan hewan dan badan-badan hukum (rechts personen) tidak dianggap sebagai subjek (Kanter \& Sinturi, 2002). Berdasarkan hal tersebut diketahui bahwa hanya manusia yang dianggap sebagai subjek tindak pidana, ini tersimpulkan antara lain dari: Perumusan delik yang selalu menentukan subjeknya dengan istilah barangsiapa, warga negara, badan hukum, korporasi, pegawai negeri, dan lain sebagainya. Penggunaan istilahistilah tersebut selain dari pada yang 
ditentukan dalam rumusan delik yang bersangkutan, ditemukan dasarnya dari pasalpasal dalam ketentuan hukum pidana.

Ketentuan mengenai pertanggungjawaban pidana seperti diatur, terutama dalam ketentuan hukum pidana, yang antara lain mengisyaratkan sebagai geestelijke vermogens dari pelaku. Ketentuan mengenai pidana yang diatur dalam ketentuan hukum pidana, terutama mengenai pidana denda, hanya manusialah yang mengerti nilai uang. Berdasarkan Pasal 55 ayat (1), (2) Kitab Undang-Undang Hukum Pidana menjelaskan bahwa dipidana sebagai pelaku tindak pidana: Mereka yang melakukan, yang menyuruh melakukan, dan turut serta melakukan perbuatan. Mereka yang dengan memberi atau menjanjikan seseuatu dengan menyalahgunakan kekuasaan atau martabat, dengan kekerasan, ancaman atau penyesetan atau dengan memberi kesempatan, sarana atau keterangan sengaja menganjurkan orang lain supaya melakukan perbuatan. Terhadap penganjur, hanya perbuatan yang sengaja dianjurkan sajalah yang diperhitungkan, beserta akibatakibatnya. Suatu konsep yang berhubungan dengan konsep kewajiban hukum adalah konsep tanggungjawab hukum. Seseorang bertanggungjawab secara hukum atas suatu perbuatan tertentu, atau memikul tanggungjawab hukum berarti bahwa dia bertanggungjawab atas suatu sanksi dalam perbuatan yang ia lakukan bertentangan dengan hukum (Jahja, 2003)

Berdasarkan hal di atas bilamana hendak menghubungkan pelaku dengan tindakannya dalam rangka pertanggungjawaban pidana pelaku tindak pidana atas tindakannya, supaya dapat ditentukan pemidanaan kepada pelaku, maka harus diteliti dan dibuktikan bahwa: Subjek harus sesuai dengan perumusan undang-undang. Terdapat kesalahan pada pelaku, Tindakan itu bersifat melawan hukum, dilarang dan diancam dengan pidana oleh undang-undang (dalam arti luas), dilakukan sesuai dengan tempat, waktu dan keadaan lainnya yang ditentukan dalam undangundang. Berdasarkan hal tersebut di atas, maka subjek pertanggungjawaban pidana pada tindak pidana pemalsuan dalam proses pembuatan akta autentik berdasarkan ketentuan undangundang adalah unsur setiap orang yang melakukan tindak pidana atau melawan hukum di mana dalam hal ini adalah notaris selaku pembuat akta, sebagaimana dirumuskan dalam undang-undang, maka orang tersebut patut mempertanggungjawabkan perbuatan sesuai dengan kesalahannya, dengan kata lain orang yang melakukan perbuatan pidana akan mempertanggungjawabkan perbuatan tersebut dengan pidana apabila ia 
mempunyai kesalahan, seseorang mempunyai kesalahan apabila pada waktu melakukan perbuatan dilihat dari segi masyarakat menunjukan pandangan normatif mengenai kesalahan yang telah dilakukan orang tersebut.

Terdapat kemungkinan 3 (tiga) macam subjek pertanggungjawaban pidana jika dilihat permasalahan dalam penelitian ini, yaitu: Pertama, Pertanggungjawaban pidana dapat dimintakan kepada notaris, pegawai notaris, dan atau klien dalam hal mereka secara bersama-sama sepakat untuk memalsukan dokumen-dokumen, tanda tangan, ataupun surat lainnya dalam rangka untuk mempercepat terbitnya akta notaris. Kedua, Pertanggungjawaban pidana dapat dimintakan kepada notaris dan pegawai notaris dalam hal notaris dan pegawai notaris secara bersama-sama sepakat untuk memalsukan dokumendokumen, tanda tangan, ataupun surat lainnya dalam rangka untuk mempercepat terbitnya akta notaris, dan dalam hal ini klien dibebaskan dari pertanggung jawaban pidana. Ketiga, Pertanggungjawaban pidana dapat dimintakan kepada klien dalam hal klien memalsukan sendiri dokumendokumen, tanda tangan, ataupun surat lainnya dalam rangka untuk mempercepat terbitnya akta notaris, dan dalam hal ini notaris dan pegawai notaris dibebaskan dari pertanggungjawaban pidana. (PN Padang, 2013)

\section{SIMPULAN}

Akibat hukum terhadap akta yang dalam proses pembuatannya mengandung unsur pemalsuan adalah terhadap akta notaris tersebut dapat dibatalkan. Akta notaris dapat dibatalkan adalah sanksi terhadap suatu perbuatan hukum yang mengandung cacat yuridis (penyebab kebatalan) berupa pembatalan perbuatan hukum atas keinginan pihak tertentu dan akibat hukum dari pembatalan itu yaitu perbuatan hukum tersebut tidak mempunyai akibat hukum sejak terjadinya pembatalan, dan pembatalan atau pengesahan perbuatan hukum tersebut tergantung pada pihak tertentu, yang menyebabkan perbuatan hukum tersebut dapat dibatalkan atau disahkan. Akta notaris harus memuat adanya kesepakatan para pihak yang akan membuat perjanjian di dalam akta notaris tersebut dan kesepakatan mereka yang mengikatkan diri terjadi secara bebas atau dengan kebebasan.

Pertanggungjawaban pidana notaris pada Putusan Pengadilan Negeri Padang Nomor 535/Pid.B/2013/PN. Pdg dalam hal akta yang dibuat notaris mengandung unsur 
pemalsuan yaitu harus memenuhi tiga unsur pertanggungjawaban pidana agar pelaku bisa mempertanggungjawabkan tindak pidana yang dilakukannya, di mana ketiga unsur itu adalah kemampuan untuk bertanggung jawab, adanya kesalahan, dan tidak adanya alasan pemaaf. Mengenai pertanggungjawaban pidana terhadap pelaku tindak pidana pemalsuan tanda tangan seseorang dalam sebuah akta autentik dalam Putusan Pengadilan Negeri Padang Nomor 535/Pid.B/2013/PN. Pdg pada dasarnya sudah memenuhi semua unsur pertanggungjawaban pidana baik dari segi kemampuan untuk bertanggung jawab, adanya kesalahan, dan tidak adanya alasan pemaaf, sehingga dalam hal ini ketiga unsur pertanggungjawaban pidana telah terpenuhi secara hukum terdakwa selaku notaris dapat dimintakan pertanggungjawaban pidana atas perbuatan tindak pidana pemalsuan tanda tangan seseorang dalam sebuah akta autentik.

\section{DAFTAR PUSTAKA}

Adjie, H. (2008). Hukum Notaris Indonesia, Tapsir Tematik Terhadap UU Nomor 30 Tahun 2004 Tentang Jabatan Notaris, Bandung, Refika Aditama.

Ali, M, (2015), Dasar-Dasar Hukum Pidana, Jakarta, Sinar Grafika.

Andrisman, T, (2007), Hukum Pidana, Bandar Lampung, Universitas Lampung.

Din, T. (2019), Pertanggungjawaban Notaris Terhadap Akta Otentik Terindikasi Pidana. Kupang, Jurnal Penelitian hukum DE JURE. Vol. 19 No. 2. Juni 2019.

Hamdan, M, (2008), Pembaharuan Hukum Tentang Alasan Penghapusan Pidana, Medan, Pustaka Bangsa Press.

Kanter, E.Y. \& Sianturi, S.R. (2002). Asas-Asas Hukum Pidana di Indonesia dan Penerapannya. Jakarta: Storia Grafika.

Kanter, E.Y. \& Sianturi, S.R. (2002). Asas-Asas Hukum Pidana di Indonesia dan Penerapannya. Jakarta: Storia Grafika.

Kitab Undang-Undang Hukum Perdata.

Kitab Undang-Undang Hukum Pidana.

Lubis, S, (1994), Etika Profesi Hukum, Jakarta, Sinar Grafika.

Moeljatno, (1993), Asas-Asas Hukum Pidana, Jakarta, Bina Aksara.

Ningsi, Faisal, Adwani, (2019), Kedudukan Notaris Sebagai Mediator Sengketa Kenotariatan Terkait denganKewajiban Penyuluhan Hukum, JIKH Vol. 13 No. 2 Juli 2019, Banda Aceh

Oloan, $N$, (2016), Praktek Pembuatan Akta Tanah oleh Camat dalam Kedudukan dan Fungsinya Selaku PPAT Sementara di Kota Padangsidimpuan, Jurnal Pendidikan Ilmu-Ilmu Sosial, 8 (2) (2016): 123131

Putri A.R. (2011). Perlindungan Hukum Terhadap Notaris Indikator Tugas-Tugas Jabatan Notaris Yang Berimplikasi Perbuatan Pidana. Jakarta: Sofmedia.

Putusan Pengadilan Negeri Padang Putusan Nomor 535/Pid.B/2013/PN.Pdg

Santoso, A. (2012). Hukum, Moral, Dan Keadilan: Sebuah Kajian Filsafat Hukum. Jakarta: Kencana Prenada Media Group.

Santoso, J. (2003), Tanggunggugat Notaris Dalam Pembuatan Keterangan Waris, Universitas Air Langga, Surabaya

Sunggono, B. (2003). Metodologi Penelitian Hukum. Jakarta: Raja Grafindo Persada.

Undang-Undang Nomor 30 Tahun 2004 Tentang Jabatan Notararis 